\title{
CORPORATE LIFE CYCLE AS DETERMINANT OF CAPITAL STRUCTURE IN COMPANIES OF CZECH AUTOMOTIVE INDUSTRY
}

\author{
P. Pinková, P. Kamínková
}

Received: November 30, 2011

\begin{abstract}
PINKOVÁ, P., KAMÍNKOVÁ, P.: Corporate life cycle as determinant of capital structure in companies of Czech automotive industry. Acta univ. agric. et silvic. Mendel. Brun., 2012, LX, No. 2, pp. 255-260

The issue of capital structure choice belongs to fundamental strategic financial decisions. A variety of potential determinants was suggested by theoreticians; however, the corporate life cycle was considered of peripheral importance, and thus the relationship between corporate life stages and capital structure was investigated only exceptionally. Both concepts were in the meantime developed separately. Recently, it has appeared that the aforementioned relation has become a subject of increased interest of the researches as a way to better understanding of how the corporate funding is changing in the course of time. The main objective of this paper is to investigate the impact of corporate life cycle on the capital structure of companies. For the purpose of the article quantitative research is used. The sample consists of fifty companies belonging to NACE division 29, manufacture of motor vehicles, trailers and semi-trailers. The data come from financial statements of the chosen companies and mostly cover a period since their start-up till year 2010. First, the method based on cash flow patterns is applied for the identification of firm's life cycle. Next, the methods of descriptive statistics and the hypothesis test about a population proportion are used. The paper explores the relationship between capital structure and corporate life cycle. The empirical study is performed to support theoretical findings.
\end{abstract}

corporate life cycle, capital structure, cash flow patterns, automotive industry, sources of finance

The issue of capital structure choice belongs to a fundamental topic in the field of financial management. One of the first and probably the most widely known is the study developed by Modigliani and Miller (1958), which became the starting point for development of other theories, such as static trade-off theory, information asymmetry theory, agency cost theory or pecking order theory.

The corporate life cycle became an interest of researchers approximately in the period when capital structure theories started to be developed. Organizational theorists such as Lippit and Schmidt (1967), Adizes (1979), Miller and Friesen (1984), Black (1998) or Levie and Lichtenstein (2008) tried to understand the corporate development by its comparison to human life cycle. More than one hundred models, generated in the last fifty years, differ not only in the number of stages and their characteristics, but mainly in the way of determination of particular phases.

There also exist many theoretical and empirical studies concerning potential determinants of capital structure choice. The assets structure, company size, non-debt tax shield, dividend policy, business risk, profitability or liquidity are those frequently mentioned.

Only some of the studies consider the organizational life stage as a possible factor. Corporate capital structure and corporate life cycle have been mostly examined separately. The pecking order theory is at least distantly related to the issue of corporate life cycle. It generally explains funding behaviour of companies that tend to use internal equity, debt and finally external equity. According to this theory, the stages of birth and growth are typical with a higher use of debt than equity. The mature 
companies decrease the level of debt, which rises again in the decline stage (Frielinghaus, Mostert \& Firer, 2005; Dickinson, 2011).

The finding of relation between the capital structure and organizational life stage could help the better understanding of how the corporate funding is changing in the course of time. Hence, the main objective of this paper is to investigate the impact of corporate life cycle on the capital structure of companies.

\section{METHODS AND RESOURCES}

The paper is based on financial data collected from the balance sheet and income statement of Czech medium-sized enterprises of automotive industry. The data were obtained from the Amadeus database.

All companies are in the legal form of a limited liability company. According to classification of economic activities in the European Community, they belong to NACE division 29, manufacture of motor vehicles, trailers and semi-trailers.

The size of the company was determined according to the European Commission Recommendation (2003/361/EC); thus, the companies had to meet the following requirements:

- the number of employees between 50 and 249,

- and either the annual turnover not exceeding 50 million $€$

- or the annual total assets not exceeding 43 million $€$.

The sampling period is 2002 to 2010 . The data mostly cover years since the start-up of selected companies to year 2010. The required minimum existence period of companies is 5 years. Cases with incomplete entries were removed. The final sample is composed by 50 companies.

The stages of corporate life cycle were determined on the basis of cash flow patterns, proposed by Dickinson (2011). The author verified the validity of cash flow patterns as indicators of firm life cycle. The nature of the method lies in the fact that each pattern can be characterized by different development of financial, operational and investment activities of companies. The basic principle of the method is depicted in Table I. The method seems applicable for the conditions of Czech companies. The main principle is supported by theoretical findings of some Czech authors, such as Kislingerová (2010). The direct method for creating a cash flow statement was implemented.
In her method, Dickinson uses five stages life cycle model which is similar to classical model of Miller and Friesen (1984).The model involves five common life stages, namely birth, growth, maturity, revival and maturity.

The capital structure of companies in different stages of corporate life-cycle was subsequently examined on the basis of selected criteria. The data were processed by standard methods of descriptive statistics and a hypothesis test about a population proportion was conducted. The hypothesis test serves to assess statistical significance of sample proportions in populations.

In accordance to Anderson (2010), three forms of the test are possible. For the purpose of the article two-tailed test was applied. The two-tailed test can be written as follows:

$$
H_{0}: p=p_{0}, H_{a}: p \neq p_{0} .
$$

The test statistic takes following form (Blatná, 2007):

$$
z=\frac{p-p_{0}}{\sqrt{\frac{p_{0}\left(1-p_{0}\right)}{n}}} .
$$

The null hypothesis is rejected on the basis of critical value approach. In the case of two-tailed test the rejection rule is (Anderson, 2010):

$$
z \leq z_{1-£ / 2} \text { and } z \geq z_{£ / 2} \text {. }
$$

The 0.05 significance level is the criterion used for rejecting the null hypothesis.

Two basic null hypotheses were established to be verified:

- There is the congruence between a debt ratio in the growth stage and a debt ratio in the maturity stage.

- There is the congruence between a ratio of longterm sources of finance in the growth stage and a ratio of long-term sources of finance in the maturity stage.

\section{RESULTS AND DISCUSSION}

There exist different approaches to defining of capital structure. The main distinction can be seen in varieties of debts involved. The first group of authors uses the broad concept comprising the use of total debt. The other group adopts the narrow approach working only with long-term debt. With

\begin{tabular}{|c|c|c|c|c|c|c|c|c|}
\hline Operating CF & $\begin{array}{c}\text { Birth } \\
-\end{array}$ & $\begin{array}{c}\text { Growth } \\
+\end{array}$ & $\begin{array}{c}\text { Maturity } \\
+\end{array}$ & \multicolumn{3}{|c|}{ Revival } & \multicolumn{2}{|c|}{ Decline } \\
\hline Investing CF & - & - & - & - & + & + & + & $T$ \\
\hline Financing CF & + & + & - & - & + & - & + & - \\
\hline
\end{tabular}
regard to article focus and a significant role of short-

I: Cash Flow patterns of individual corporate life stages

Source: Dickinson (2011) 
term liabilities in the funding of Czech companies, the broad concept is applied and the capital structure is described according to Synek (2011) as the structure of financial resources from which the company's assets were acquired.

\section{Criteria for assessment of capital structure}

The sources of finance can be classified on different basis (Gitman, 2006; Kislingerová, 2010; Synek \& Kislingerová, 2010). For the purpose of the article, the classification according to ownership and control over the business and the classification according to time period are applicable. They will serve as criteria for evaluation of capital structure.

According to ownership and control over the business, which is from a perspective of providers of financial sources, can be distinguished:

- Equity (or owned) capital.

- Debt (or borrowed) capital.

Equity capital is sourced from the owners of the company or from the company's own activities. Own sources are as follows: share capital, retained earnings or other shareholders' funds. Debt capital is the capital raised from outside sources. For example, it includes long-term and short term payables, provisions, bank loans and other current and non-current liabilities.
In the context of time period two basic types of financial sources are distinguished. These are:

- Long-term financial sources.

- Short-term financial sources.

Long-term financial sources are used in the long term (over one year); some of them are part of capital structure for an unrestricted period of time. They can be in a form of shareholders' equity or long-term liabilities, namely share capital, retained earnings, other shareholders' funds, long-term bank loans and other non-current liabilities. Short-term financial sources are payable within one year. They include items such as short-term bank loans, shortterm payables and other current liabilities.

\section{Capital structure according to selected criteria}

In total, 311 cases of corporate life cycle stages were determined. All five kinds of phases were present. Nevertheless, almost half of the companies occurred in the maturity stage and on the contrary, the stages of revival and decline were identified only exceptionally. Both the birth phase and the growth phase held approximately 15 percent share.

Graph 1 depicts the average capital structure from the perspective of providers of financial sources.

It is evident that the equity ratio gradually rises from the birth to maturity stage. The maturity stage

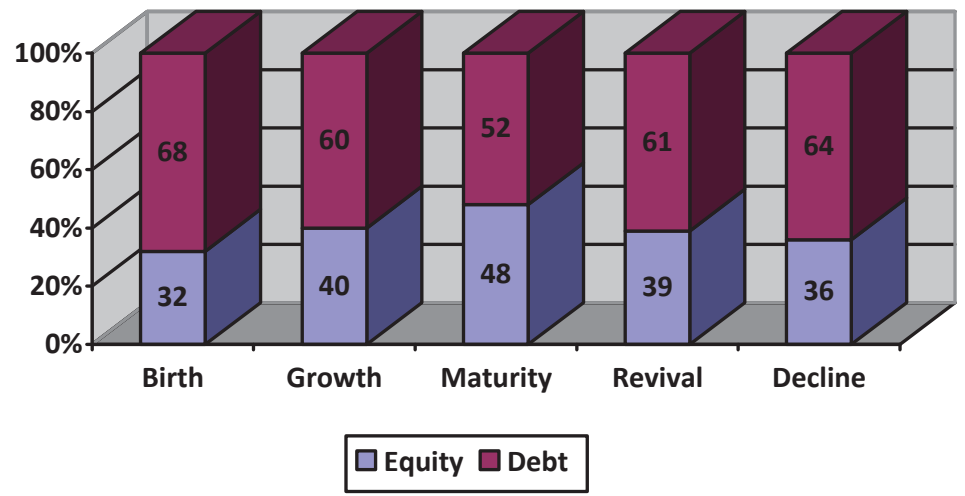

1: Capital structure according to ownership and control Source: own results

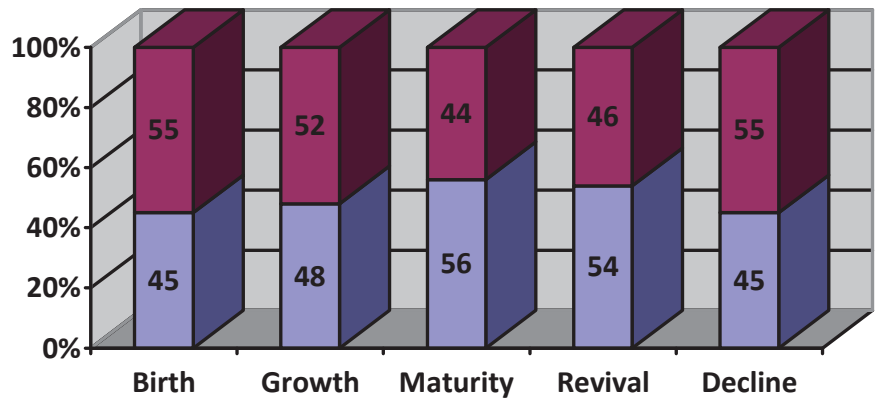

$\square$ Long-term Capital $\square$ Short-term Capital

2: Capital structure according to time period

Source: own results 
represents the peak of equity utilization, after which follows the decrease of equity size in the stages of revival and decline. The curve of the graph is similar to the development of corporate life cycle's curve.

The development of equity ratio resembles the findings of the pecking order theory. The early and late stages of corporate life cycle are typical with lower use of equity financing. Contrarily, the higher level of equity is expected in the maturity stage.

Graph 2 describes the average capital structure in different stages of corporate life cycle from time point of view. High level of usage of short-term liabilities is noticeable in all involved phases. The course of development is similar to a previous case. The level of long term assets increases in the early phases. The highest long-term debt ratio can be found in the maturity stage. The modest decline in long-term capital is demonstrated in the revival stage, followed by higher decrease in the decline stage.

Graph 3 shows the mode structure of financial resources. It describes the capital structure that occurred most frequently in particular stages. The graph's curve resembles the curve from the previous cases, but the concrete values vary in higher degree.

The highest level of debt is used in the birth stage. The level is even greater than in the decline stage. The usage proportion of short-term liabilities in the birth stage can be considered as quite surprising. On the contrary, the ratio of current liabilities to total liabilities in the decline stage is as expected. The lowest debt, both long-term and short-term, is used in the maturity phase.

The hypothesis test about a population proportion was performed repetitively for each of possible combination of corporate life-cycle stages. In total, twenty different null hypotheses were examined. The test results are involved in Table II.

In fourteen cases, the null hypothesis cannot be rejected at the 0.05 level, which would mean that there is the congruence between capital structure ratios in different life-cycle stages. In six cases, the null hypothesis was rejected and the alternative hypothesis was accepted. No congruence between the ratios would mean that there exist a relation between the capital structure and corporate life cycle and the corporate funding is influenced by the life-cycle stage.

The contradictory results can be caused by insufficient number of companies occurred in the stage of revival and decline. The larger size of the sample would provide a higher precision of results and a smaller margin of error.

\section{CONCLUSIONS}

The study confirmed the fact that companies do not have to go through the stages of corporate life cycle gradually, but the order of stages can vary in dependence of concrete conditions. Even though

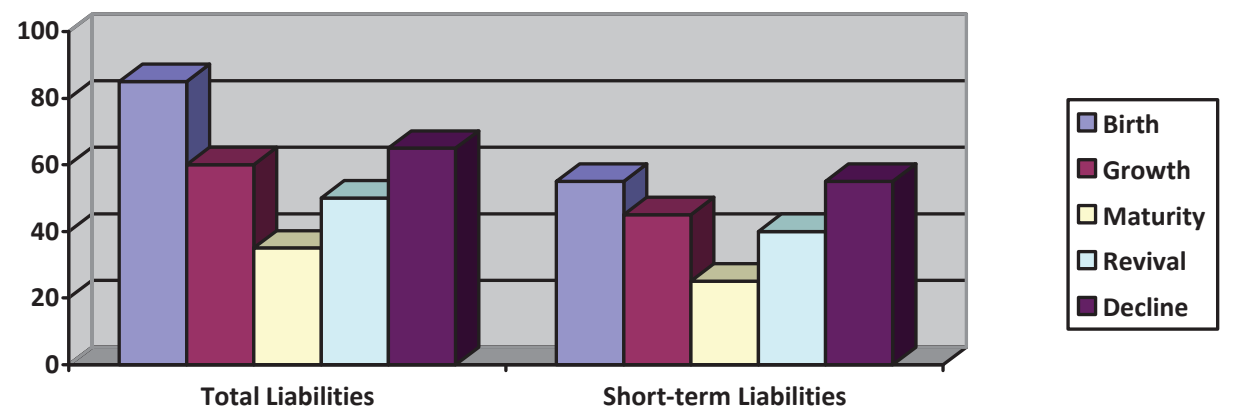

3: Liabilities ratio in different stages of corporate life cycle Source: own results

II: Hypothesis test results

\begin{tabular}{lcc}
\hline \multicolumn{1}{c}{ Combination of CLC stages } & Debt Ratio & Long-term financial sources ratio \\
\hline Birth \& Growth & $\mathrm{H}_{0}: \mathrm{p}=\mathrm{p}_{0}$ & $\mathbf{H}_{\mathbf{a}}: \mathbf{p} \neq \mathbf{p}_{\mathbf{0}}$ \\
Birth \& Maturity & $\mathbf{H}_{\mathbf{a}}: \mathbf{p} \neq \mathbf{p}_{\mathbf{0}}$ & $\mathbf{H}_{\mathbf{a}}: \mathbf{p} \neq \mathbf{p}_{\mathbf{0}}$ \\
Birth \& Revival & $\mathrm{H}_{0}: \mathrm{p}=\mathrm{p}_{0}$ & $\mathrm{H}_{0}: \mathrm{p}=\mathrm{p}_{0}$ \\
Birth \& Decline & $\mathrm{H}_{0}: \mathrm{p}=\mathrm{p}_{0}$ & $\mathrm{H}_{0}: \mathrm{p}=\mathrm{p}_{0}$ \\
Growth \& Maturity & $\mathbf{H}_{\mathbf{a}}: \mathbf{p} \neq \mathbf{p}_{0}$ & $\mathbf{H}_{\mathbf{a}}: \mathbf{p} \neq \mathbf{p}_{0}$ \\
Growth \& Revival & $\mathbf{H}_{\mathbf{a}}: \mathbf{p} \neq \mathbf{p}_{0}$ & $\mathrm{H}_{0}: \mathrm{p}=\mathrm{p}_{0}$ \\
Growth \& Decline & $\mathrm{H}_{0}: \mathrm{p}=\mathrm{p}_{0}$ & $\mathrm{H}_{0}: \mathrm{p}=\mathrm{p}_{0}$ \\
Maturity \& Revival & $\mathrm{H}_{0}: \mathrm{p}=\mathrm{p}_{0}$ & $\mathrm{H}_{0}: \mathrm{p}=\mathrm{p}_{0}$ \\
Maturity \& Decline & $\mathrm{H}_{0}: \mathrm{p}=\mathrm{p}_{0}$ & $\mathrm{H}_{0}: \mathrm{p}=\mathrm{p}_{0}$ \\
Revival \& Decline & $\mathrm{H}_{0}: \mathrm{p}=\mathrm{p}_{0}$ & $\mathrm{H}_{0}: \mathrm{p}=\mathrm{p}_{0}$ \\
\hline
\end{tabular}


311 different stages of corporate life cycle were determined, not all types were represented in the same proportion.

The development of debt ratio seems to be dependent on corporate life cycle stages. The results of the study resemble in many aspects the findings of pecking order theory. The stages of birth, growth and decline are typical with higher level of debt use. The equity capital is preferred in the maturity stage.
The results of hypothesis testing were ambiguous. This ambiguity might be connected with lower occurrence of some of the stages.

In conclusion, it can be assumed that the relation between the life stage and capital structure exists. Definitely, in the future it would be appropriate to repeat the study with larger sample size.

\section{SUMMARY}

The paper deals with the issue of capital structure in the context of corporate life cycle. The main objective is to investigate the impact of corporate life cycle on the capital structure of companies. The quantitative research is applied. The sample consists of fifty medium-sized companies belonging to NACE division 29, manufacture of motor vehicles, trailers and semi-trailers. The sampling period is 2002 to 2010. The method of cash flow patterns is used for determination of corporate life cycle phases. The data are processed by standard methods of descriptive statistics and a hypothesis test about a population proportion is conducted. Both the development of debt-to-equity ratio and the development of current liabilities in different stages of corporate life cycle indicate the linkage between organizational life cycle and capital structure. However, the results of hypothesis testing were ambiguous, which can be caused by insufficient occurrence of some of the stages. The overall results of the study resemble in many aspects the findings of pecking order theory.

\section{REFERENCES}

ADIZES, I., 1979: Organizational passages Diagnosing and treating lifecycle problems of organizations. Organizational Dynamics, 8(1), $3-25$.

ANDERSON, D. R. et al., 2010: Statistics for Business and Economics. South-Western College Pub. ISBN 978-0324783247.

BLACK, E. L., 1998: Life-cycle impacts on the incremental value relevance of earnings and cash flows measures. Journal of Financial Statement Analysis, 4(1), 40-56.

BLATNÁ, D., 2003: Statistika a pravděpodobnost. Bankovní institut vysoká škola, ISBN 9788072650590.

DICKINSON, V., 2011: Cash Flow Patterns as a Proxy for Firm Life Cycle. The Accounting Review. 19 Apr, 2011. [online] Available on http://ssrn.com/ abstract $=755804$.

EC, 2003: EC recommendation concerning the definition of micro, small and mediumsized enterprises. [online] Available on http:// ec.europa.eu/enterprise/policies/sme/factsfigures-analysis/sme-definition/index_en.htm.

FRIELINGHAUS, A., MOSTERT, B. \& FIRER, C., 2005: Capital structure and the firm's life stage. Africa 36, 9-18.
GITMAN, L. J., 2006: Essentials of Managerial Finance: Addison Wesley. ISBN 0-321-35648-9.

KISLINGEROVÁ, E. a kol., 2010: Manažerské finance. Praha: C. H. Beck. 3. vyd. ISBN 978-807400-194-9.

LEWIE, J. \& LICHTENSTEIN, B. B., 2008: From "Stages" of Business Growth to a Dynamic States Model of Entrepreneurial Growth and Change. Hunter Centre for Entrepreneurship University of Svathclyde, Working Paper WP 08-02.

LIPPIT, G. L. \& SCHMIDT, W. H., 1967: Crises in a developing organization. Harvard Business Review, 47, 102-112.

MILLER, D. \& FRIESEN, P. H., 1984: A longitudinal study of corporate life cycle. Management Science, 30(10), 1161-1183.

MODIGLIANI, F. \& MILLER, M. H., 1958: The Cost of Capital, Corporate finance and the Theory of Investment. American Economic Review, 48, 261296.

SYNEK, M. a kol., 2011: Manažerská ekonomika. Praha: Grada Publishing. 5. vyd. ISBN 978-80-2473494-1.

SYNEK, M., KISLINGEROVÁ, E. a kol., 2010: Podniková ekonomika. Praha: C. H. Beck. 5. vyd. ISBN 978-80-7400-336-3.

Ing. Bc. Pavlína Pinková, Ing. Petra Kamínková, Ústav podnikové ekonomiky, Mendelova univerzita v Brně, Zemědělská 1,61300 Brno, Česká republika, e-mail:pinkova@node.mendelu.cz, xkaminko@node.mendelu. 
